\title{
The Roxburghe Club Collection
}

\author{
VA L ER I E M. L A G ORIO
}

The University of Iowa Libraries' Special Collections Department contains a truly remarkable collection of publications of the Roxburghe Club-remarkable since all editions were and continue to be limited to the membership of the club, with the total number of copies not to exceed 100, according to the club's rules and regulations. From its inception to the present day, the club's membership resembles Burke's Peerage, supplemented by a few notable Americans and Europeans, the majority of whom either own or are associated with libraries, and by some leading scholars. As the oldest extant bibliophilic society in Great Britain, if not the world, the Roxburghe Club has exerted a positive influence on the world of books in preserving medieval and Renaissance texts which might otherwise have been lost, stimulating the collecting of books by the affluent, viewing the book as an artifact and consequently upholding the highest standards of typography and book production, and inspiring the foundation of such scholarly and bibliophilic associations as the Bannatyne (for Scottish literature and documents), Percy (for shorter medieval poems, ballads, and broadsides), Hakluyt (for travel and geography), Camden, Surtees, New Shakespeare, Wyclif, Browning, and Shelley societies, and, above all, the Early English Text Society, specializing in scholarly editions of Anglo-Saxon and medieval literature and lore, which incidentally undertook critical editions of not a few works that first appeared under the Roxburghe aegis. ${ }^{1}$

Founded on June 17, 1812, on the occasion of the sale of the Duke of Roxburghe's library, and specifically his edition of Boccaccio's Decameron, printed in 1471 by Valdarfer, the 18 original members, drawn for the most part from prominent and affluent noble families,

1 John Buechler, "The Roxburghe Club," College and Research Libraries, 19 (1958), p. 23. 
proposed that, in the alphabetical order of their names, each should underwrite and present the society with a reprint of a rare or obscure composition, preferably poetry, concentrating on minor authors rather than Chaucer, Shakespeare, and Milton. The presentation of books to the members was to be made annually on the anniversary of the first meeting. According to Nicolas Barker,

This double event, part private and part public, forms a watershed in the history of book-collecting, and, in the widest sense, of bibliography. ... The list of publications over the past 150 years provides a peculiarly fascinating cross-section of the changes in the study of books which have taken place in this time. ${ }^{2}$

During its early years, the club was better known for its gourmet and gourmand proclivities than for its bibliophilic and scholarly pursuits, ${ }^{3}$ but almost immediately established its continuing reputation for producing beautiful books through long-standing associations with illustrious printers like William Bulmer (1816-22), his successor William Nicol (1822-54), Nichols (1855-1906), the Lee Priory Press, Chiswick Press, and, after 1908, the Oxford and Cambridge University presses. Although the majority of books produced during the club's early period can be classified as ephemera of some historical or antiquarian interest, it did produce, in 1818, two books repr'nted from medieval manuscripts: John Gower's Balades and Other Poems (no. 19) and J. H. Markland's edition of the Chester Mysteries (no. 21), the latter setting a standard for subsequent editions of medieval dramatic texts; and, in 1819, Le Morte Arthur: Harley MS. 2252 (no. 25), which was not only the first printing of this important version of the Arthurian legend, but also the first manuscript taken from an institutional rather than a private library. In 1827, possibly to counteract their reputation as bibliomaniac bon vivants, but also to ensure the ongoing publication of books, the members voted to subsidize the printing of books by the club, rather than relying solely on individuals, and, for the first time, engaged the services of a nonmember scholar, Sir Frederick Madden, then assistant keeper of the manuscripts in the British Museum. Madden's editing of Havelok the Dane (no. 46), the first book sponsored by the club as a whole;

2 Nicolas Barker, The Publications of the Roxburghe Club, 1814-1962 (Cambridge: Cambridge University Press, 1964), p. 1. Volume numbers in this study are taken from Barker's Bibliographical Table, pp. 67-99. An asterisk indicates that the volume is in The University of Iowa Special Collections Department.

3 Clive Bigham, The Roxburghe Club: Its History and Its Members, 1812 1927 (Oxford: Oxford University Press, 1928), pp. 3-6. 
William and the Werewolf (no. 48); and Gesta Romanorum (no. 55 ) established new norms for scholarly editions of medieval texts, and greatly enhanced the club's repute as a literary society. ${ }^{4}$

The club's predilection for literature of the Middle Ages is manifest in 48 of its publications, including such well-known works as Poems Written during Captivity by Charles, Duke of Orleans (no. 44), The Owl and the Nightingale (no. 54), The Alliterative Romance of Alexander (no. 67 $)$, Gower's Vox Clamantis (no. $69^{\circ}$ ), The Romaunce of the Sowdone of Babylone (no. $71^{\circ}$ ), Dan Michel's Ayenbite of Inwyt (no. 72"), erroneously ascribed to Richard Rolle, Hoccleve's De Regimine Principum (no. 79), The History of the Holy

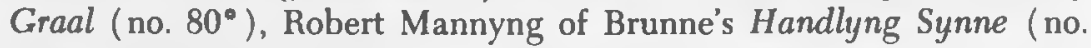
$81^{\circ}$ ), Partenope of Blois (no. 82\%), Walter Map's La Queste del Saint Graal (no. 84 $4^{\circ}$ ), The Bukes of Sir John Maundeuill (no. $119^{\circ}$ ), The Parlement of the Thre Ages (no. $132^{\circ}$ ), Titus and Vespasian (no. $146^{\circ}$ ), The Mirrour of the Blessed Lyf of Jesu Christ (no. 151 ${ }^{\circ}$ ), and five editions of Guillaume de Deguileville's Pelerinage (no. $91^{\circ}$, no. $124^{\circ}$, no. $127^{\circ}$, no. $145^{\circ}$, no. $159^{\circ}$ ). The editors of much of this medieval canon were well-known scholars: in addition to Sir Frederick Madden, one can point to the Reverend J. Stevenson, Thomas Wright, A. W. Pollard, J. A. Herbert, and F. J. Furnivall. Furnivall, in particular, objected to the club's policy of strictly limited editions of heretofore unpublished texts (a criticism which had been voiced by others in the past), as he was vitally involved in preserving, editing, and disseminating medieval texts in the interests of promoting scholarship in this area. Accordingly, he tactfully divorced himself from the Roxburghe group to devote his energies to the Early English Text Society and other societies which he had founded. The importance and worth of the club's medieval publications were unrivaled until 1858, when the Rolls Series began its publications of English historical texts and records, and also until the Early English Text Society assumed the leadership for publishing Anglo-Saxon and medieval critical editions.

In addition to medieval works, the club continued to publish correspondence, memoirs, diaries, and historical documents, many of which are unique to the Roxburghe collection, some travel literature and cartography, ballads, and other musical texts. The club reached its nadir at the meeting of 1884 , when the question of whether or

4 Robert W. and Gretchen P. Ackerman, Sir Frederick Madden. A Bibliographical Sketch and Bibliography (New York \& London: Garland Publishing, Inc., 1979), pp. 46-47, 51-52, 57. 
not to continue was raised, and seven of the nine attending members voted to go on. It was during this same period that its modern interest in manuscript facsimiles flourished, impelled in part by the superior photolithographical talents of Emery Walker, William Griggs and the collotype process employed by the Autotype Company. ${ }^{5}$ The Apocalypse of St. John (no. 103 ) was the Roxburghers' first complete manuscript facsimile, to be followed by Les Miracles de Nostre Dame (no. $114^{\circ}$ ) and The Metz Pontifical (no. 138 $8^{\circ}$ ), both of which reflected the club's growing interest in artistic reproduction as well as textual transcription.

The Roxburghe Club's commitment to paleography and manuscript illuminations, manifest in the largest segment of its modern editions, received an added impetus from the membership (1909-36) of Montague R. James, who, along with Delisle, Sir George Warner, and $\mathrm{E}$. M. Thompson, perfected the methodology of manuscript description, transcription, and critical assessment. James edited 13 manuscript facsimilies for the club, among them The Trinity College Apocalypse (no. $155^{\circ}$ ), The Chaundler Manuscripts (no. $169^{\circ}$ ), La Estoire de Seint Aedward le Rei (no. $175^{\circ}$ ), Illustrations of the Book of Genesis (no. $177^{\circ}$ ), A Petersborough Psalter and Bestiary of the XIVth Century (no. $178^{\circ}$ ), The Apocalypse in Latin and French (no. $180^{\circ}$ ), and The Bestiary (no. $190^{\circ}$ ), the latter a complete facsimile of a Cambridge manuscript with a 60-page introduction on the Physiologus tradition in England.

Other outstanding manuscript facsimiles are Thirty-two Miniatures from the Book of Hours of Joan II, Queen of Navarre (no. 137'); The Pageants of Richard Beauchamp Earl of Warwick (no. 150 $0^{\circ}$ ), which was the first Roxburghe book published by a university press; The Gospels of Matilda, Countess of Tuscany, 105.5-1115 (no. 172 ${ }^{\circ}$ ), presented by J. Pierpont Morgan, Jr. for his father; The Sherborne Missal (no. $176^{\circ}$ ); The Bohun Manuscripts (no. 200'); The Rutland Psalter (no. $213^{\circ}$ ); A Thirteenth-Century York Psalter (no. $216^{\circ}$ ); and An Illuminated Manuscript of La Somme le Roy, attributed to the Parisian Miniaturist Honoré (no. 219 $9^{\circ}$ ). This concentration on facsimiles and concomitant scholarship also prevails in the club's 13 most recent books, published between 1964 and 1977, all of which are at Iowa.

The University of Iowa Libraries have 156 of the 241 volumes in the Roxburghe Club series, with the largest lacunae occurring in the

5 Barker, pp. 37-49. 
early publications. This holding is of great interest to literary scholars, historians, art historians, bibliographers, and bibliophiles, and is yet another example of the richness, worth, and variety of the UI Libraries' resources.

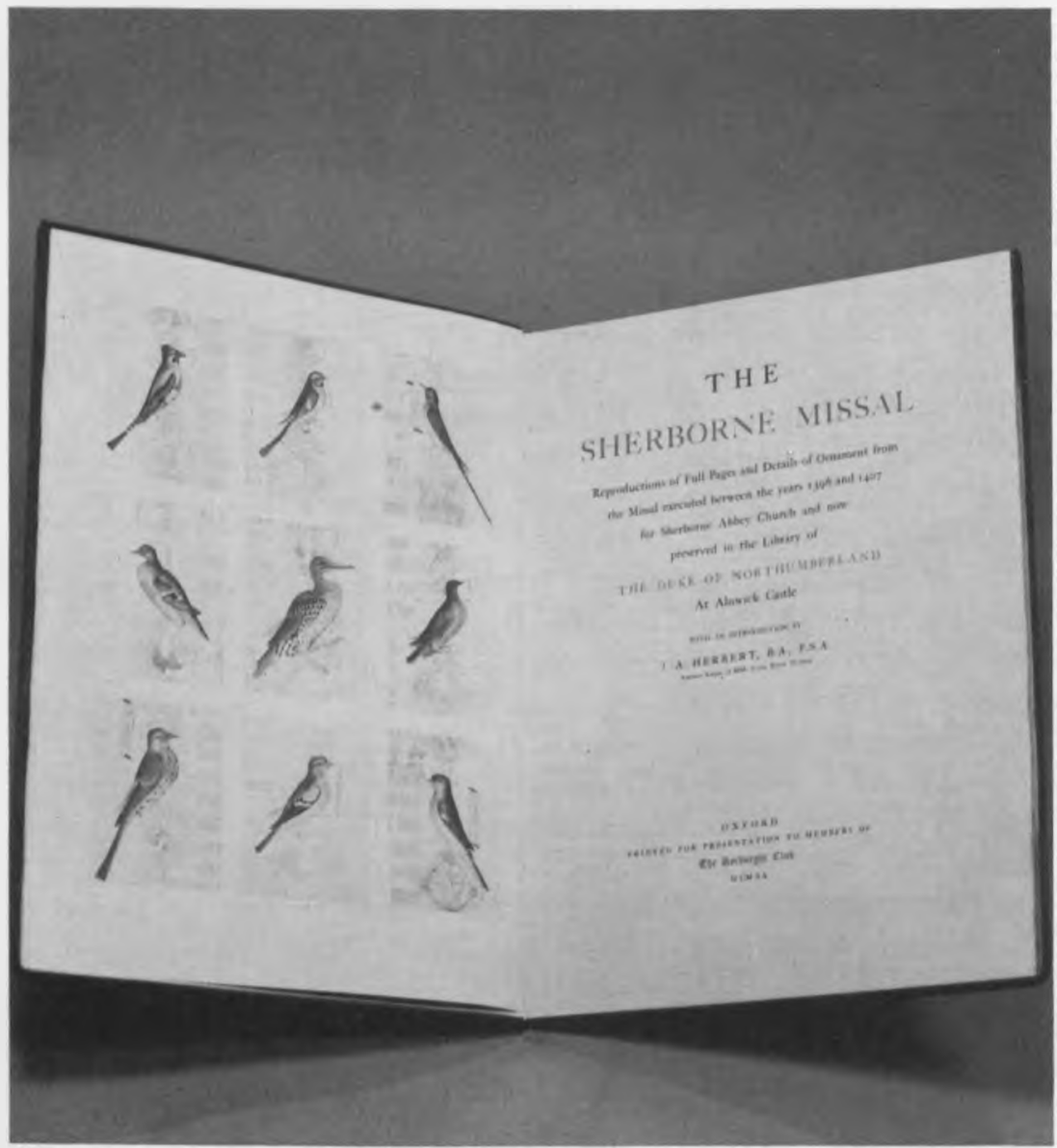

Among the medieval manuscripts reproduced for the Roxburghe Club is The Sherbome Missal, presented to members by the Duke of Northumberland in 1920 . Its colored frontispiece, decorated with real rather than legendary birds, is a fine example of color collotype. The University of lowa copy, shown above, originally belonged to the Earl of Derby. 